\title{
Growth of Mya arenaria L. at the northern edge of the range: heterogeneity of soft-shell clam growth characteristics in the White Sea
}

\author{
Alexandra V. Gerasimova*, Fedor M. Martynov, Nadezhda A. Filippova and Nikolay V. Maximovich
}

\begin{abstract}
Linear growth of soft-shell clams, Mya arenaria L., was studied at six locations in the White Sea situated in the middle and low tidal zones. The main aim was to analyse the growth heterogeneity both within beds (with respect to individual growth) and between beds (with respect to group growth). Mya population was characterized by a slow growth and a long lifespan. Maximum shell size was $70-80 \mathrm{~mm}$, and longevity was at least 25 years. In addition, growth rates were highly variable, statistically significant differences being present both within and between the beds. No differences were found in group growth between different tidal horizons of the same site. The slowest growth of soft-shell clams was observed at sites with the greatest content of fine particles (silt and clay) in sediments. Differences between beds in Mya group growth could reflect variability of feeding conditions, which were probably determined by some local features (e.g. hydrodynamic regime). However, the variation of the individual growth rate within beds was comparable to that of the group growth rate between studied locations. To a great extent it seemed to be determined by the characteristics of the initial period of soft-shell clam growth.
\end{abstract}

Keywords: Bivalvia, Mya arenaria, Length growth, Individual and group growth, White Sea

\section{Background}

Growth patterns of aquatic organisms are important characteristics of their populations, primarily as integrated indicators of habitat conditions. Bivalves are a convenient object for comparative studies of length growth since their age could be rather easily and reliably determined by counting annual shell growth marks. Examining intrapopulation heterogeneity of the molluscan growth is valuable in the ecological context. In some cases, the growth rate variability in different habitats of the same area and within the range of the species can be quite comparable [31, 65].

Growth rate heterogeneity within molluscan populations is usually studied in two respects. Numerous studies deal with the impact of various environmental factors

*Correspondence: agerasimova64@mail.ru

Department of Ichthyology and Hydrobiology, St. Petersburg State University, 16th Line VO, 29, St. Petersburg, Russia 199178 on bivalve growth rate heterogeneity in different beds of the same species $[4,18,25,28,52,56,62]$. Beds (or local populations) are relatively dense aggregations formed in typical habitats and can be considered a characteristic form of intrapopulation organization of marine benthos [26]. Environmental factors considered usually include water temperature, salinity, and feeding conditions [64]. The most important among the latter are the concentration and quality of organic particles, duration of air exposure, water current velocity, and population density.

At the same time, an increasing attention is currently being paid to studies of molluscan growth heterogeneity within a single bed $[65,64,11,24,51,54,70]$. Differences in the individual growth rate within one habitat are apparently associated with the impact of factors of "individual" action, such as reproduction condition, size, age, and genetic characteristics of individuals as well as with interannual differences in environmental conditions [64]. To note, most if not all studies of individual growth rate 
of bivalves at the White Sea have concerned Mytilus edulis $[65,64,54,60,63]$.

The soft-shell clam, Mya arenaria L., is a common boreal species inhabiting soft sediment. Due to several life history traits, it is a convenient model for population research. Adult clams can burrow into sediments down to a depth of $30-50 \mathrm{~cm}$ and do not change their habitat throughout their lifetime [66]. Therefore, the characteristics of their growth should reflect local environment conditions.

Growth rate and lifespan of soft-shell clams have been studied repeatedly in different geographical locations such as the North Atlantic [2, 7, 8, 12, 46, 58], the Kattegat [44], the Baltic Sea [23], the White Sea [37, 53, 57]. In some cases, the results of these observations showed a significant variation even within the same region. For the White Sea, the estimates of Mya lifespan varied from $7-8$ to 25 years $[37,53,57]$. To a large extent, this could be explained by difficulties in using external shell morphology for age determination [2, 33, 40]. Growth of $M y a$ arenaria can be affected by water temperature and salinity $[2,12]$, sediment type $[47,67]$, and nutritional conditions $[52,7,6,14,48]$. According to some researchers [2, 12], the temperature regime is a major cause of latitudinal growth changes of Mya arenaria, while other factors (salinity, duration of air exposure, water current velocity, sediment characteristics) lead to variability in growth parameters within local regions $[52,2,7,46,53,47,67$, 30]. Mya growth rate is higher in the lower intertidal zone and in upper subtidal zone $[52,7,46]$. There is a negative correlation between Mya growth rate and silting of the sediments [2]. Nevertheless, variability in growth characteristics of Mya arenaria within beds mostly remains unstudied.

Long-term (since 1980) observations of the structure of soft-shell clam beds have been performed at four typical tidal beaches of the Keret Archipelago in the White Sea $[26,37,27]$. The most prominent trait of these $M y a$ beds was a pronounced dominance of a few generations over a considerable period of time (up to 15 years). Those were the 1988 and the 1999 generations. Due to a virtual absence of recruitment for a long period (5-11 years), these generations were relatively easy to distinguish from the others (by external shell morphology) at any given time. Therefore, both individual and group (average) growth parameters of 1988 and 1999 generations were identified with a high reliability. So these generations were used for the analysis of growth characteristic heterogeneity. The main aim was to analyse the growth heterogeneity both within beds (with respect to individual growth) and between beds (with respect to group growth).

\section{Methods \\ Study area}

This study was carried out at the Marine Biological Station of the Saint Petersburg State University (MBS St.P.S.U., Fig. 1) located in the Chupa Inlet mouth (Kandalaksha Bay, the White Sea). Mya arenaria beds were studied at the vicinity of MBS St.P.S.U. at four beaches of the Keret Archipelago (sites): (1) silty-sand beach in the Lebyazhya bight (lat. $66^{\circ} 17^{\prime} \mathrm{N}$; long. $33^{\circ} 35^{\prime} \mathrm{E}$ ); (2) silty-clay-sand beach in the Sukhaya Salma Strait (lat. $66^{\circ} 31^{\prime} \mathrm{N}$; long. $33^{\circ} 65^{\prime} \mathrm{E}$ ); (3) silty-sand beach at Bolshoi Gorely Island (lat. $66^{\circ} 32^{\prime} \mathrm{N}$; long. $33^{\circ} 64^{\prime} \mathrm{E}$ ); and (4) sandy beach with some silt in the Yakovleva bight (lat. $66^{\circ} 32^{\prime} \mathrm{N}$; long. $33^{\circ} 83^{\prime} \mathrm{E}$ ) (Fig. 1). Mya arenaria beds were observed from 1980 to 2013 at site 1, from 1989 to 1997 at site 2, and from 2000 to 2006 at sites 3 and 4 [26]. Observations were carried out at 1 - to 3 -year intervals mostly between late June and late July. Detailed description of sampling methods is provided in earlier publications [26, 37, 27]. At sites 1 and 2, molluscs were collected in the middle and low tidal zones and, at sites 3 and 4, only in the middle tidal zone (there were no soft-shell clams in the low tidal zone). Samples from different locations (e.g. middle tidal and low tidal zones) within each site were treated separately. Aggregation of molluscs in each tidal level (location) was regarded as an individual bed. In the Kandalaksha Bay, the amplitude of the tide does not normally exceed 2-2.5 m [9]. In the low tidal zone, samples were taken $20-30 \mathrm{~cm}$ above zero depth and, in the middle tidal zone, at $60-70 \mathrm{~cm}$ above zero depth. Samples were taken using series of frames with an area of $0.01-1 \mathrm{~m}^{2}$.

In the summer of 2004, sediment samples were taken at all the studied sites for the analysis of particle size distribution. Sediments were excavated up to $5 \mathrm{~cm}$ depth (3 samples at each location). The following fractions were registered for the analysis of particle size distribution: more than $10,10-5,5-3,3-1,1-0.5,0.5-0.25,0.25-0.1$, $0.1-0.05,0.05-0.01,0.01-0.005 \mathrm{~mm}$. The analysis was performed using the standard procedure in two stages [50]: (1) the determination of the proportion of coarse fractions by sieving the sediments through mesh sieves of $10,5,3,1,0.5,0.25 \mathrm{~mm}$ and (2) separating sediments into fractions of $0.25-0.1$ and $0.1-0.05,0.05-0.01,0.01-$ $0.005 \mathrm{~mm}$ using aqueous analysis.

\section{Sample processing}

Shell length of Mya arenaria was measured to the nearest $0.1 \mathrm{~mm}$. Age of molluscs was determined by counting annual growth marks on shells $[37,27]$. An average shell length of the dominant generation (1988 or 1999) was determined at each sampling. As a result, the growth parameters of Mya arenaria were determined for a large 


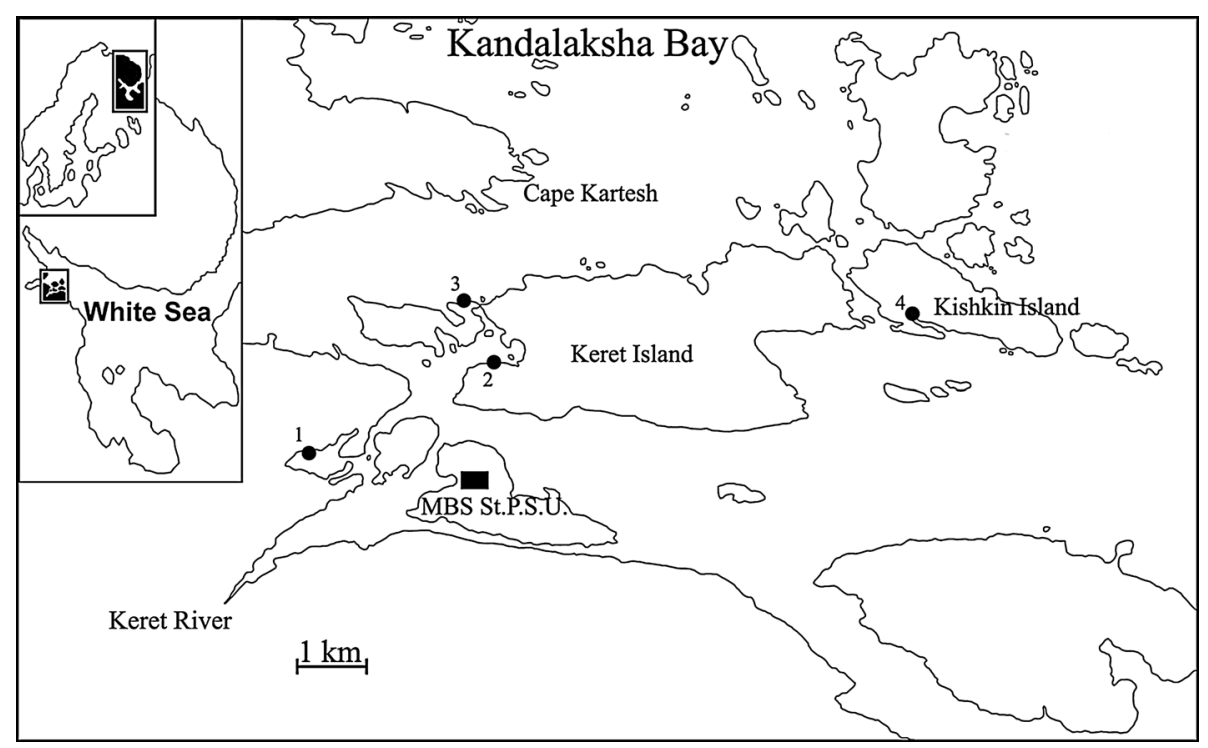

Fig. 1 Study area. 1-4-investigated sites

part of mollusc life cycle (from 7 years at sites 3 and 4 to 25 years at site 1 ).

Both individual and group (average) growth characteristics of the 1988 and the 1999 generations were used to analyse the variability of $M y a$ growth rate at the studied beds. Individual growth history of each clam (individual age row) was reconstructed by measuring the shell length during all winter growth delays. Individual age rows were used to assess growth heterogeneity within beds. Group growth parameters of the 1988 or the 1999 generations (group age rows) were obtained for each bed by averaging individual growth characteristics. Group age rows were used in the study of the growth characteristic heterogeneity between different beds.

For growth pattern reconstruction, the von Bertalanffy equation was used:

$$
L_{t}=L_{\infty}\left(1-\exp ^{-k\left(t-t_{0}\right)}\right)
$$

where $L_{t}$ is the shell length $(\mathrm{mm})$ at time $t$ (year); $L_{\infty}$ (asymptotic or theoretically maximal length, $\mathrm{mm}$ ), $k$ (rate at which $L_{\infty}$ is approached, year ${ }^{-1}$ ), and $t_{\mathrm{o}}$ (theoretical time at which $L_{t}=0$, year) are constants.

Growth rows were compared according to an algorithm suggested by Maximovich [35]: a pairwise comparison of growth rows and their clustering was carried out using the analysis of residual variances with regard to growth curves. Significance of variance distinctions was estimated by Fisher's $F$-statistic $(F)$. The ratio of Fisher's $F$-statistic to the critical $F$ value at $P<0.05, F / F_{\text {cr }}$, was used as a measure of distance between the compared rows. $F / F_{\mathrm{cr}}<1$ meant the absence of significant differences between the compared growth rows. Clustering was performed using the method of weighed pairgroup average. If the age rows did not indicate that the growth rate slowed down with age, then the von Bertalanffy equation could not be used for their approximation [35]. In these cases, the age rows were approximated for cluster analysis by the linear equation:

$$
L_{t}=a+b t
$$

where $a$ and $b$ are constants.

\section{Analysis of growth heterogeneity within the beds}

Variation of growth characteristics within each bed was studied by comparing individual age rows of 5 -year-old clams of the 1988 generation (sites 1 and 2) or the 1999 generation (sites 3 and 4). This age group was chosen for several reasons. First, the comparison of age series using the proposed algorithm [35] was possible only in molluscs older than 5 years. According to this algorithm, each age row should comprise at least 4 measurements, but the first growth mark (corresponding to the growth delay during the first winter after settlement) was not visible in specimens older than 2 years [27]. So the youngest specimens suitable for the age row comparison were 5 -year-old clams. Furthermore, only clams with distinguishable marks of winter growth delay were suitable for the analysis. Observations at sites 3 and 4 ceased in 2006, when clams of the 1999 generation were 7 years old. There were relatively few clams at these sites, and growth rows could be reconstructed only for a few individuals. In 2005, when clams of the 1999 generation were 6 years 
old, no observations at these sites were made. Meanwhile, the 5-year-old clams of the 1988 and the 1999 generations were relatively numerous in the respective beds and mostly had well-defined marks of winter growth delay. Therefore, the analysis of individual growth heterogeneity was based on 5-year-old clams.

In individual beds 22 to 111, 5-year-old molluscs were used for the analysis (for sites 1, 2 from 1993 sampling and for sites 3, 4 from 2004 sampling). We intended to involve into the analysis the representatives of all size groups. Due to the insufficient data about the life cycle, the age rows were approximated by a linear Eq. (1).

We tried to find a correlation between the individual variability of Mya arenaria growth rate within beds and the features of the initial growth period. Annual shell length increment in some bivalves is known to correlate with the initial size (that is, the size before the start of the growing season) $[64,24,54,15,38,41$, 55]. The dependence of Mya arenaria size by the end of the first year of life on the size of the first winter growth delay was assessed in each bed using Spearman's rank correlation coefficient (at significance level $\alpha \leq 0.05)$.

\section{Analysis of growth heterogeneity between the beds}

Variation of growth characteristics between different beds ( 6 beds overall) was studied in two ways.

Firstly, the group age rows were compared. They were constructed for the 1988 generation at sites 1 and 2 and for the 1999 generation at sites 3 and 4. The length of group age rows was aligned for all studied beds. The study of the 1999 generation at sites 3 and 4 was completed in 2006 when the clams were 7 years old. Therefore, only the data on the first 7 years were used for the other studied beds as well: sampling 1989-1995 at sites 1 and 2 and sampling 2000-2006 at sites 3 and 4 .

Secondly, variation of growth characteristics between different beds was studied based on the results of the analysis of individual growth within beds. When comparing individual age rows in each bed, the clams were divided into clusters, each cluster comprising specimens with no significant differences of growth characteristics. The average growth characteristics were identified for each cluster. In this way, the group growth rows constructed for 5-year-old clams were also used to compare the growth in different beds.

\section{Results}

\section{Abiotic conditions}

The study sites were typical of the tidal zone of the Keret Archipelago. Their hydrological regime corresponded to that of the White Sea coastal zone in general [5]. All study sites were located in semi-closed areas and differed slightly in respect of salinity and sediment type. The surface salinity in the Lebyazhya bight (site 1) was relatively low, no more than 14-17\% in summer, because of a nearby river estuary $[37,27]$. The surface salinity at other sites ranged from 24 to $26 \%$ in summer [5]. As shown by analysis of sediment grain size distribution, sand was the base fraction at all study sites (from $42 \%$ at site 1 , MT, to $85 \%$ at site 4 ) (Table 1). This fraction included $50-90 \%$ of fine sand (particle size of $0.25-0.1 \mathrm{~mm}$ ). The maximum amount of other fine fractions (clay and silt; particles less than $0.1 \mathrm{~mm}$ ) was recorded at sites 2 and 3 (33 and $38 \%$, respectively), and the lowest amount (12\%) was registered at site 4 .

\section{Growth rate, lifespan, and maximum size of Mya arenaria at the study sites}

The greatest differences between the average growth rate of the 1988 and the 1999 generations at the study sites were observed during first five years of molluscan life: from $4 \mathrm{~mm}$ per year (sites 2,3 ) to $7 \mathrm{~mm}$ per year (site 4) (Table 2). At all the locations clams maintained a relatively high growth rate during the first 7-10 years: an average of $3 \mathrm{~mm}$ (MT_2) $-5 \mathrm{~mm}$ (MT_4) per year (Fig. 2). Clams older than 15 years (site 1) had the lowest growth rate, less than $1-1.5 \mathrm{~mm}$ per year.

The observations at site 1 continued throughout the whole life cycle of the 1988 generation, ending with

\section{Table 1 Grain size distribution in sediments}

\begin{tabular}{lllllll}
\hline $\begin{array}{l}\text { Location } \\
\text { (tidal zone_site) }\end{array}$ & \multicolumn{2}{l}{ Sediment composition (average \pm SE), \% } & & \\
\cline { 2 - 7 } & Pebble & Gravel & Coarse sand & Medium sand & Fine sand & Silt and clay \\
& $\mathbf{1 0}$ & $\mathbf{1 0 - 1}$ & $\mathbf{1 - 0 . 5}$ & $\mathbf{0 . 5}-\mathbf{0 . 2 5}$ & $\mathbf{0 . 2 5}-\mathbf{0 . 1}$ & $<\mathbf{0 . 1}$ \\
\hline MT_1 & $9.9 \pm 0.9$ & $19.5 \pm 1.1$ & $8.3 \pm 0.7$ & $9.0 \pm 2.3$ & $25.3 \pm 1.9$ & $27.9 \pm 0.9$ \\
LT_1 & $6.4 \pm 0.6$ & $17.4 \pm 1.5$ & $11.2 \pm 0.9$ & $13.0 \pm 0.5$ & $23.9 \pm 0.9$ & $28.2 \pm 3.1$ \\
LT_2 & $0.41 \pm 0.05$ & $0.8 \pm 0.07$ & $0.87 \pm 0.05$ & $3.6 \pm 0.8$ & $61.5 \pm 1.8$ & $32.9 \pm 2.1$ \\
MT_3 & $5.8 \pm 0.4$ & & $7.1 \pm 0.8$ & $9.5 \pm 1.6$ & $39.2 \pm 3.1$ & $38.4 \pm 1.1$ \\
MT_4 & $3.1 \pm 0.5$ & & $12.6 \pm 1.1$ & $32.5 \pm 4.1$ & $40.0 \pm 2.4$ & $11.9 \pm 0.8$ \\
\hline
\end{tabular}

$M T$ and $L T$ middle and low tidal zones, respectively; SE standard error 
Table 2 Dynamics of average shell length $(L \pm S E, \mathrm{~mm})$ of the 1988 (sites 1, 2) and $1999($ sites 3, 4) generations of Mya arenaria

\begin{tabular}{|c|c|c|c|c|c|c|}
\hline \multirow[t]{3}{*}{ Age (years) } & \multicolumn{6}{|l|}{$L \pm S E$} \\
\hline & \multicolumn{6}{|c|}{ Location name ${ }^{a}$} \\
\hline & MT_1 & LT_1 & MT_2 & LT_2 & MT_3 & MT_4 \\
\hline 1 & $8.2 \pm 0.1$ & $9.2 \pm 0.1$ & $5.4 \pm 0.1$ & $7.1 \pm 0.1$ & $4.2 \pm 0.1$ & $7.4 \pm 0.3$ \\
\hline 2 & $12.0 \pm 0.1$ & $13.9 \pm 0.2$ & $9.1 \pm 0.2$ & $9.9 \pm 0.2$ & $8.1 \pm 0.2$ & $11.1 \pm 0.3$ \\
\hline 3 & $15.8 \pm 0.3$ & $17.0 \pm 0.1$ & $14.1 \pm 0.2$ & $14.4 \pm 0.2$ & $12.2 \pm 0.2$ & $14.3 \pm 0.3$ \\
\hline 4 & - & $22.1 \pm 0.2$ & $19.4 \pm 0.3$ & $19.1 \pm 0.2$ & $15.9 \pm 0.3$ & $25.7 \pm 0.5$ \\
\hline 5 & $24.3 \pm 0.4$ & $25.0 \pm 0.2$ & $20.3 \pm 0.4$ & $19.5 \pm 0.3$ & $17.5 \pm 0.2$ & $35.7 \pm 0.5$ \\
\hline 6 & - & $29.4 \pm 0.3$ & - & - & - & - \\
\hline 7 & $30.1 \pm 0.7$ & $31.9 \pm 0.4$ & $24.0 \pm 0.5$ & $30.0 \pm 0.5$ & $25.5 \pm 1.4$ & $35.8 \pm 0.9$ \\
\hline 8 & $34.1 \pm 0.6$ & $36.9 \pm 0.8$ & $25.9 \pm 0.4$ & $28.7 \pm 0.7$ & - & - \\
\hline 9 & $34.5 \pm 0.5$ & $38.1 \pm 0.3$ & $30.1 \pm 2.1$ & $31.7 \pm 1.6$ & - & - \\
\hline 10 & $39.5 \pm 1.0$ & $41.7 \pm 0.4$ & - & - & - & - \\
\hline 11 & $43.0 \pm 0.4$ & $43.0 \pm 0.4$ & - & - & - & - \\
\hline 12 & $47.1 \pm 1.2$ & $45.1 \pm 0.4$ & - & - & - & - \\
\hline 13 & $46.2 \pm 1.1$ & $50.1 \pm 0.6$ & - & - & - & - \\
\hline 14 & $48.5 \pm 0.8$ & $50.3 \pm 0.5$ & - & - & - & - \\
\hline 15 & $52.8 \pm 1.3$ & $50.9 \pm 0.5$ & - & - & - & - \\
\hline 16 & $50.3 \pm 1.5$ & $50.2 \pm 0.8$ & - & - & - & - \\
\hline 17 & - & - & - & - & - & - \\
\hline 18 & $62.6 \pm 1.6$ & $56.4 \pm 1.0$ & - & - & - & - \\
\hline 19 & $57.6 \pm 2.2$ & $53.6 \pm 1.3$ & - & - & - & - \\
\hline 20 & $57.3 \pm 1.8$ & $57.4 \pm 1.3$ & - & - & - & - \\
\hline 21 & - & - & - & - & - & - \\
\hline 22 & - & $59.0 \pm 1.1$ & - & - & - & - \\
\hline 23 & $62.1 \pm 3.2$ & $58.6 \pm 1.1$ & - & - & - & - \\
\hline 24 & - & $60.6 \pm 1.8$ & - & - & - & - \\
\hline 25 & - & $59.2 \pm 1.3$ & - & - & - & - \\
\hline$L_{\infty}$ & 82.02 & 67.16 & 37.50 & 59.80 & 128.10 & 68.17 \\
\hline k & 0.06 & 0.09 & 0.16 & 0.08 & 0.03 & 0.12 \\
\hline$t_{0}$ & -0.50 & -0.43 & 0.07 & -0.40 & -0.14 & 0.35 \\
\hline$L_{\max }$ (age, years) & $71(20)$ & $70(20)$ & $46(9)$ & $37(8)$ & $38(7)$ & $50(7)$ \\
\hline
\end{tabular}

the death of its last representatives. The oldest clam of this generation found at the middle intertidal zone was 23 years old and at the low intertidal zone, 25 years old. The maximum shell length of clams was about $70 \mathrm{~mm}$ (20 years old). This was close to the maximum clam sizes found at this site throughout the observation period, $72 \mathrm{~mm}$ at MT and $79 \mathrm{~mm}$ at LT.

The observation periods at the other sites were much shorter, 7 years at sites 3 and 4, and 9 years at site 2 (Table 2). Single individuals of the 1988 generation must have survived at site 2 after the end of observations in
1997. Similarly, the 1999 generation was not entirely eliminated at sites 3 and 4 by the end of observations in 2006. This indicates that the maximum size and age recorded for molluscs of the 1988 and the 1999 generations at sites 2-4 were not the maximum possible ones. Noteworthy, specimens with a length of 75 and $78 \mathrm{~mm}$ were found at different times at sites 2 and 4, respectively. Unfortunately, their age could not be reliably determined on the basis of external shell morphology due to shell erosion near the hinge and the convergence of the rings at the shell edge. 


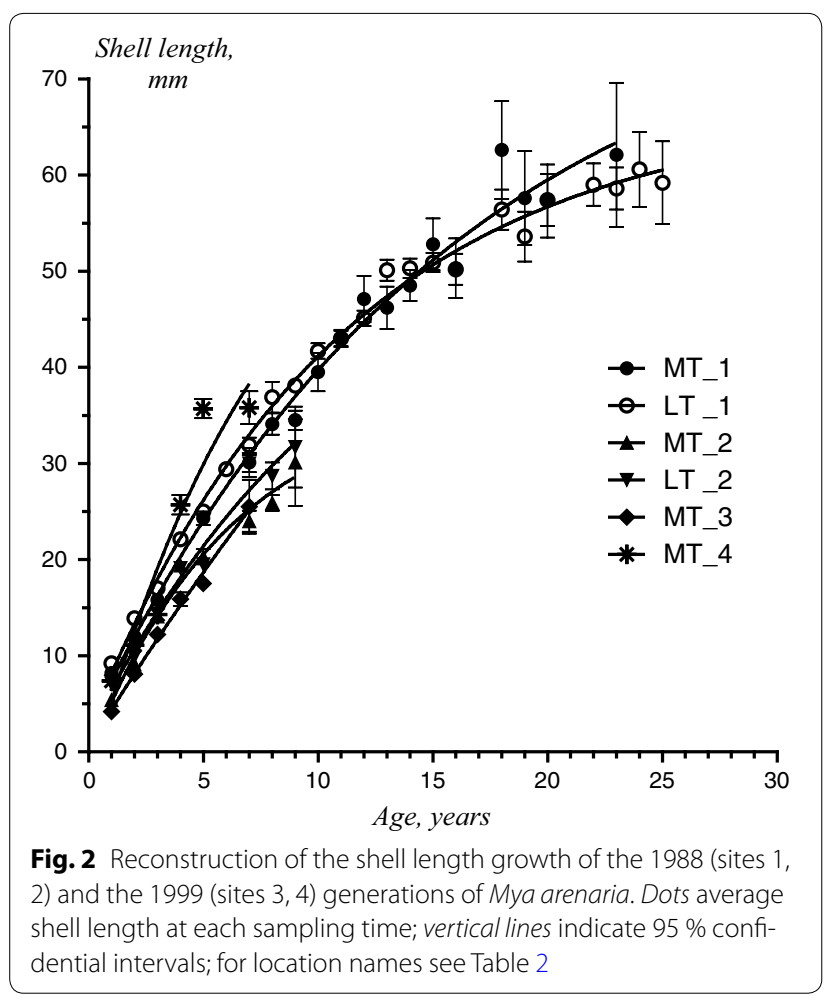

Individual variability of growth characteristics within the beds

The differences between individual growth rates of the 1988 and the 1999 generations of soft-shell clams within the beds were highly significant. The size of 5-year-old clams varied by a factor of 2-4. For example, the shell length of 5-year-old individuals at location MT_1 varied from 11 to $43 \mathrm{~mm}$.

Three to seven groups of molluscs with no significant differences of growth characteristics were obtained using cluster analysis (Table 3 ). As an example, Fig. 3 shows a similarity dendrogram of 25 clam age rows of the 1988 generation sampled at location MT_2. Using comparative analysis, the complex of rows was divided into three clusters uniting specimens with no significant differences of growth characteristics. The group growth reconstruction in the clusters is shown in Fig. 4 (MT_2). Interestingly, the distinctions between group growth models were manifested as early as at the time of the second winter growth delay (Fig. 4) and persisted afterwards. Almost no cases of compensatory growth were registered.

Comparison of individual age rows yielded generally similar patterns (Fig. 5). So we looked for correlations between the shell length by the end of the first year of life

Table 3 Growth characteristics of 5-year-old Mya arenaria of the 1988 and 1999 generations (samplings of 1993 and 2004, respectively) and results of individual age rows comparison

\begin{tabular}{|c|c|c|c|c|c|c|c|c|c|}
\hline \multirow[t]{3}{*}{ Location } & \multirow[t]{3}{*}{ Characteristics } & \multirow[t]{3}{*}{ Shell length $(\mathrm{mm})$} & \multicolumn{5}{|c|}{ Shell length during winter growth delay (mm) } & \multirow[t]{3}{*}{$N$} & \multirow[t]{3}{*}{$A$} \\
\hline & & & \multicolumn{5}{|c|}{ Number of the growth marks } & & \\
\hline & & & 1 & 2 & 3 & 4 & 5 & & \\
\hline \multirow[t]{3}{*}{ MT_1 } & Min & 11.4 & - & 3.5 & 8.2 & 11.7 & 13.1 & 60 & 5 \\
\hline & Max & 43.0 & - & 14.6 & 24.9 & 35.2 & 41.2 & & \\
\hline & Average & $24.3 \pm 0.6$ & - & $7.5 \pm 0.3$ & $13.8 \pm 0.4$ & $19.2 \pm 0.5$ & $23.0 \pm 0.6$ & & \\
\hline \multirow[t]{3}{*}{ LT_1 } & Min & 10.2 & - & 4.5 & 6.6 & 10.2 & 11.8 & 111 & 4 \\
\hline & Max & 38.1 & - & 15.5 & 25.8 & 33.2 & 37.0 & & \\
\hline & Average \pm SE & $25.0 \pm 0.5$ & - & $9.4 \pm 0.2$ & $16.1 \pm 0.4$ & $21.0 \pm 0.5$ & $23.7 \pm 0.5$ & & \\
\hline \multirow[t]{3}{*}{ MT_2 } & Min & 13.5 & - & 5.4 & 8.9 & 10.9 & 13.4 & 25 & 3 \\
\hline & Max & 29.2 & - & 10.2 & 17.6 & 23.1 & 26.3 & & \\
\hline & Average \pm SE & $20.3 \pm 0.6$ & - & $7.3 \pm 0.2$ & $12.4 \pm 0.5$ & $16.3 \pm 0.6$ & $19.5 \pm 0.7$ & & \\
\hline \multirow[t]{3}{*}{ LT_2 } & Min & 10.6 & - & 4.4 & 7.5 & 12.6 & 16.4 & 22 & 4 \\
\hline & Max & 31.0 & - & 11.5 & 21.2 & 26.3 & 29.8 & & \\
\hline & Average \pm SE & $19.5 \pm 0.5$ & - & $6.8 \pm 0.7$ & $11.6 \pm 0.8$ & $15.8 \pm 1.5$ & $18.6 \pm 1.6$ & & \\
\hline \multirow[t]{3}{*}{ MT_3 } & Min & 11.4 & - & 3.8 & 6.3 & 8.0 & 10.0 & 79 & 7 \\
\hline & Max & 26.6 & - & 10.4 & 16.0 & 20.7 & 23.8 & & \\
\hline & Average $\pm S E$ & $17.5 \pm 0.2$ & - & $6.4 \pm 0.3$ & $9.5 \pm 0.2$ & $12.4 \pm 0.2$ & $15.4 \pm 0.2$ & & \\
\hline \multirow[t]{3}{*}{ MT_4 } & Min & 26.4 & - & 4.7 & 10.0 & 15.8 & 20.7 & 70 & 4 \\
\hline & Max & 45.6 & - & 13.6 & 20.7 & 30.6 & 39.7 & & \\
\hline & Average \pm SE & $35.7 \pm 0.6$ & - & $7.9 \pm 0.2$ & $15.7 \pm 0.3$ & $22.6 \pm 0.4$ & $30.6 \pm 0.5$ & & \\
\hline
\end{tabular}

Max, Min, Average maximum, minimum, and average size, respectively, $S E$ standard error, $N$ sample size, $A$ the number of groups received by cluster analysis; for location names see Table 2; dash no data 


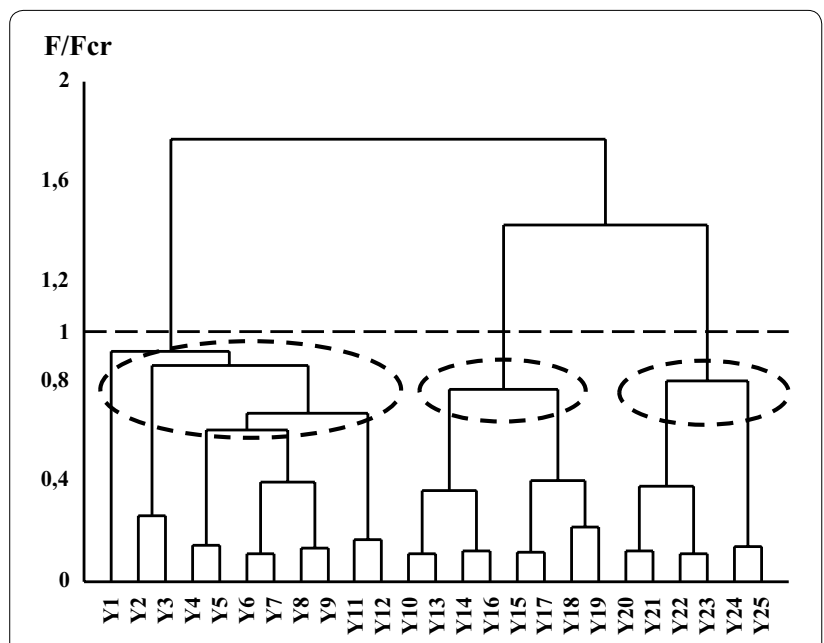

Fig. 3 Similarity dendrogram of age rows of the 1999 generation sampled in 2004 (location MT_2). Vertical axis is ratio F/F cri circles show clusters of age rows with no significant distinctions and the size of the first winter growth delay. This analysis involved soft-shell clams collected in 1989 at sites 1 , 2 and those collected in 2000 at sites 3 and 4. The relation between the parameters appeared to be almost linear (Fig. 6). Spearman's rank correlation coefficient was statistically significant in all the cases $(\mathrm{p}<0.05)$, ranging from 0.72 to 0.87 .

\section{Variability of group growth between the beds}

The group age rows of 5-year-old clams (Fig. 4) were used for the assessment of growth variation between different locations. As a result, a complex of 27 rows was formed where each bed was represented by 3 to 7 age rows. The complex was divided into 7 groups with the help of cluster analysis (Fig. 7). The only age row, which did not enter into any association, was that of MT_3. It comprised the most slow-growing molluscs, $12 \mathrm{~mm}$ over the five years of life. Soft-shell clams from site 1 demonstrated an almost

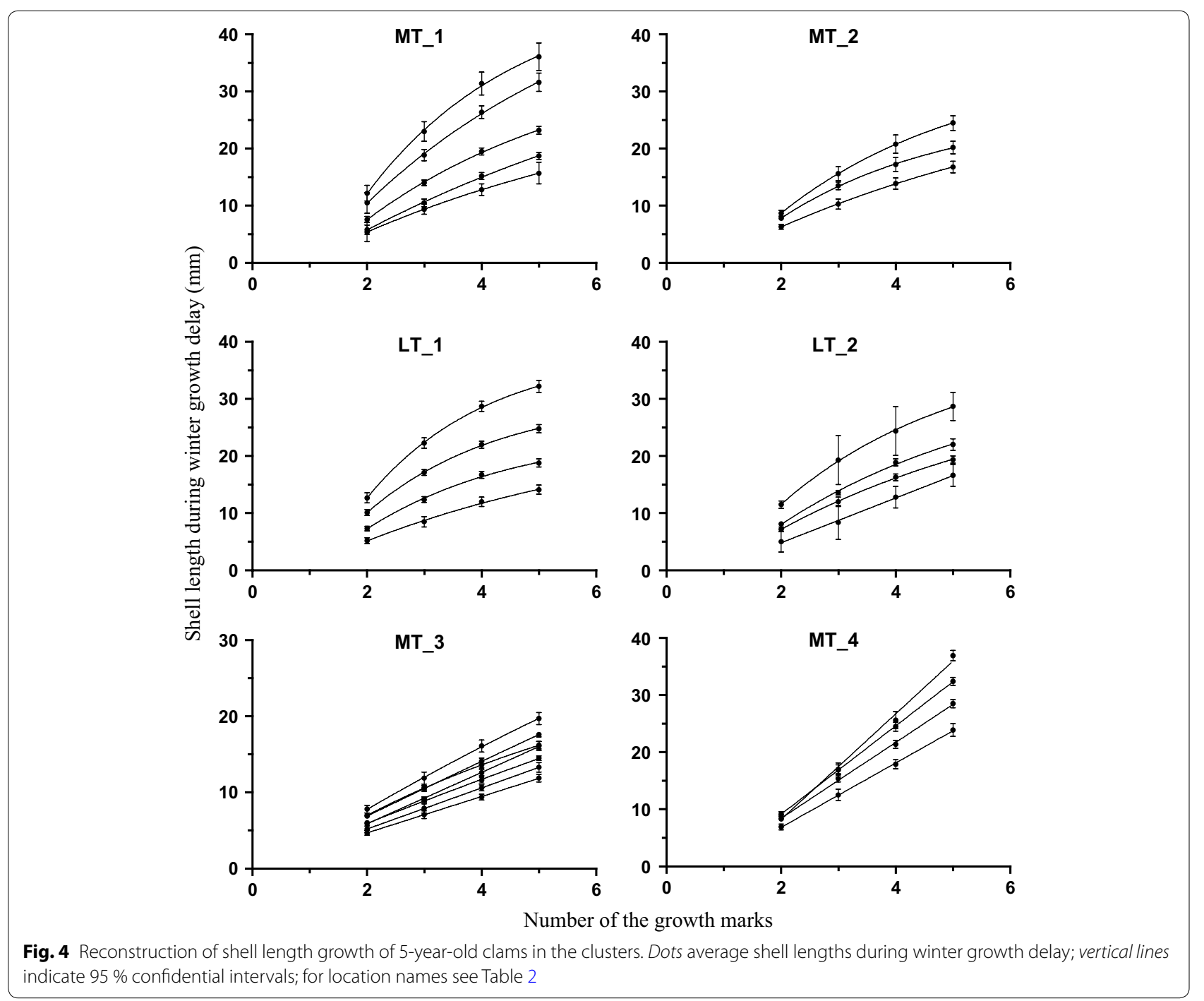




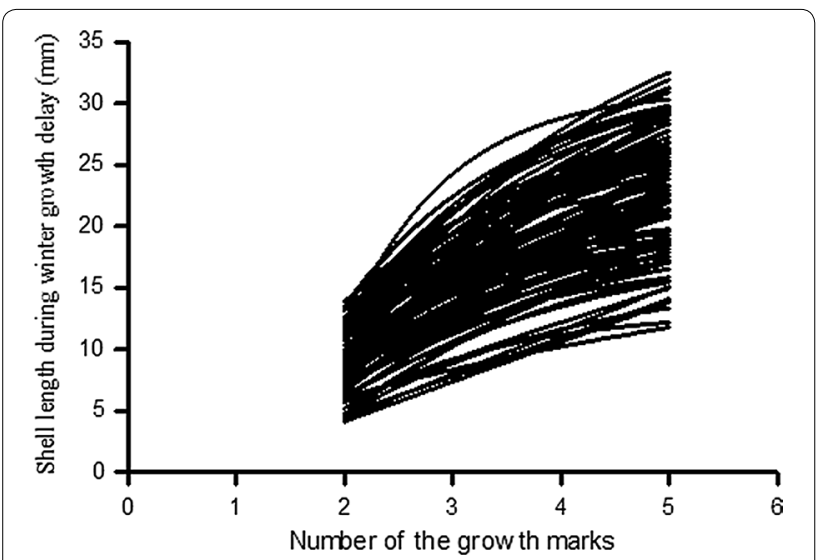

Fig. 5 Growth curves of individual clams of the 1988 generation at location LT_1 (data of 1993)

entire range of growth variability in the study area (Fig. 8). Group rows of the site included both the slowest-growing (Cluster 1) and the fastest-growing clams (Cluster 7). Mya arenaria from locations MT_3 and MT_4 demonstrated extreme variants of the growth rate. Soft-shell clams from location $\mathrm{MT}_{-} 3$ were characterized by a relatively low growth rate and were allocated mostly in the lower part of Fig. 8. By contrast, clams at location MT_4, by contrast, were characterized by a relatively high growth rate and were allocated mostly in the upper part of Fig. 8. The growth curves constructed for site 2 (both LT_2 and MT_2) formed the central part of Fig. 8.

The comparative analysis of growth of 5-year-old clams from different beds had some deficiencies. For example, each row consisted of four successive measurements only (shell length during 2-5 winter growth delay), while the size of the first growth ring remained unknown. However, as shown before, the initial stages of growth may have a significant impact on later growth rate. Therefore, the average sizes of Mya arenaria during 1-7 winter growth delays in each bed (Table 4) were estimated using data on 1989-1995 and on 2000-2006 for sites 3 and 4 . These age rows were also used for comparing the growth in different beds. It was found that the mean size during 7 winter growth delays differed by almost one and half in different beds, varying from $23 \mathrm{~mm}$ (location MT_2) to $34 \mathrm{~mm}$ (location MT_4) (Table 4). No significant differences were found between clams from site 1 and site 4 as a result of statistical comparison of age rows (the rows were approximated by the von Bertalanffy model) (Fig. 9). These clams had the highest growth rate, $31-34 \mathrm{~mm}$ in 7 years (Fig. 10). At the other beds (sites 2 and 3), the growth rate was significantly lower, $22-27 \mathrm{~mm}$ in 7 years (Figs. 9, 10). Interestingly, the slowest growth was observed at sites with the greatest content of fine particles (silt and clay) in sediments, 33-38\% (Table 1). At site 4, where the fastest growth was observed, the proportion of silt and clay was the lowest, about $12 \%$.

\section{Discussion}

Group growth

One of the most substantial results in this study was determination of maximum longevity of Mya arenaria in the White Sea, which was found to be no less than 25 years. Predominance of a single generation in Mya arenaria beds and its long-term monitoring during virtually the entire Mya life cycle helped a lot to make this conclusion [26, 27]. This is much more than previously reported for the White Sea soft-shell clams (from 7-8 to 17 years) [37, 53, 57, 34, 36]. The lifespan of Mya was probably underestimated in previous studies due to difficulties in age determination using external shell morphology [40], namely, the lack of clear first-year growth lines due to erosion of the shell near the hinge and the convergence of growth lines formed during the later stages of the life cycle.

Our results on the maximum lifespan (at least 25 years) and the maximum shell length $(72-79 \mathrm{~mm})$ of Mya arenaria agree with those from other parts of the distribution area, where longevity varied from 4 to 28 years and maximum length ranged from 27 to $150 \mathrm{~mm}$ [33, 3, 13, $16,19,20,21,68]$. However, the maximum growth rate in our study was much lower than that in other areas of Mya arenaria distribution, especially the Atlantic coast of North America. In our study, the length of 7-year-old clams was $24-36 \mathrm{~mm}$, while in the mid-Atlantic Mya arenaria reached an average size of $150 \mathrm{~mm}$ by the age of 8 [1], and in southern Baltic, $40 \mathrm{~mm}$ by the age of 5 [23].

The slow growth of soft-shell clams revealed in our study may be associated with severe temperature conditions and low salinity $[37,5]$. Negative seawater temperatures (down to $-1.5{ }^{\circ} \mathrm{C}$ ) are observed in the study area from late November to late April, while in the summer the 2-m upper water layer warms up to $15-17{ }^{\circ} \mathrm{C}$. The salinity in summer is as little as 14-17\%o at site 1 and 24-26\% at other sites. Low salinity is known to have a negative influence on the growth of soft-shell clams [2, $12,46]$. However, there were no substantial differences in Mya growth rate at sites 1 and 4, which differed considerably in respect of salinity. At the same time, Mya group growth was quite different at sites 3 and 4 despite similar salinity conditions. In addition, a much faster growth of Mya arenaria (40 mm over 5 years) was found in the southern Baltic [23], where surface salinity was even lower than in our study (5\%). As the feeding conditions (the rate of primary production) are quite close in the Kandalaksha Bay of the White Sea and in the southern Baltic [10, 22], a possible reason of a faster growth of the 


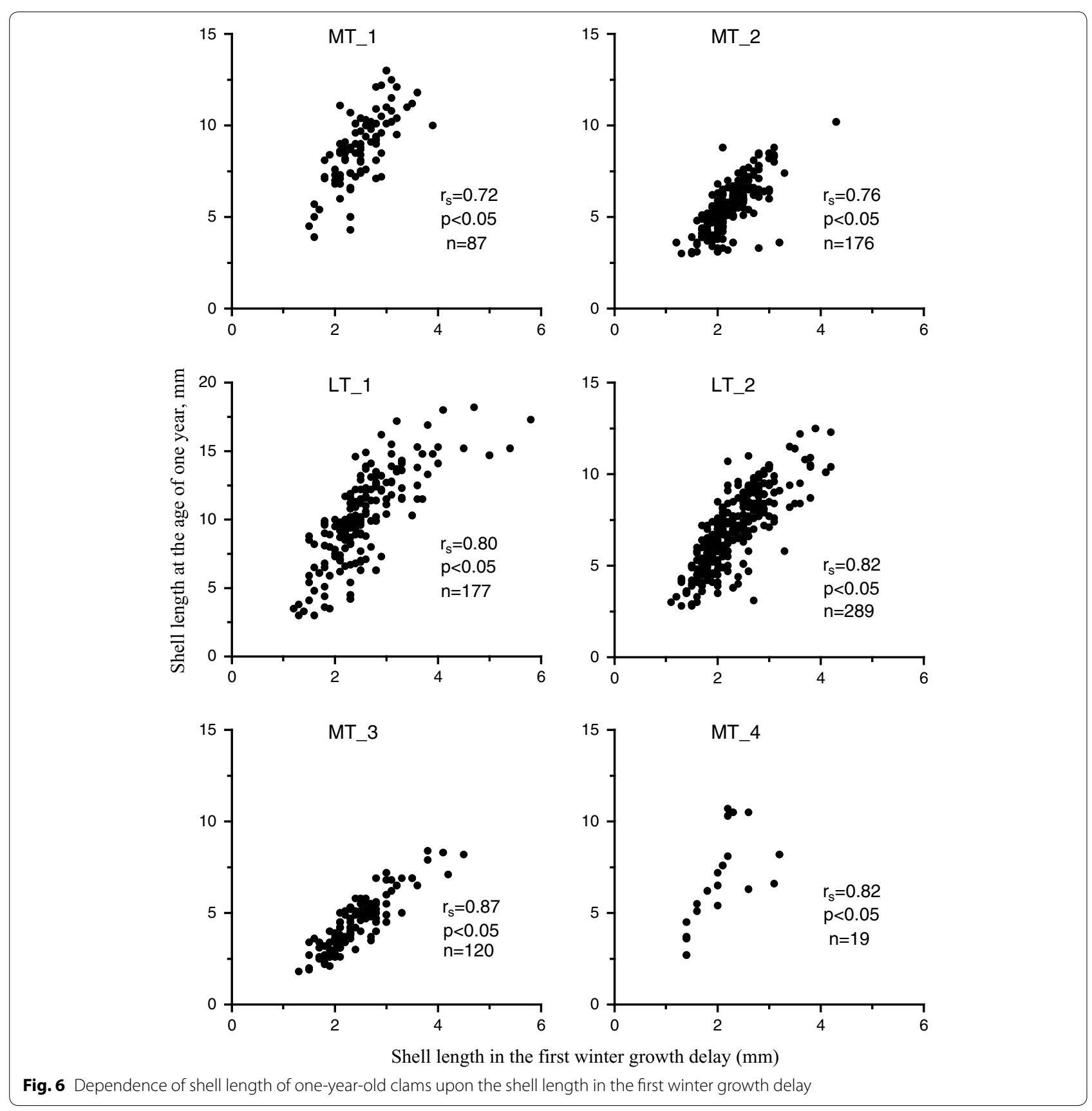

soft-shell clams in the latter area might be more favourable temperature conditions (the absence of negative temperatures in winter).

The differences in Mya group growth at different sites in our study might be associated with some local features. Temperature regime, though known to affect the growth rate of bivalves-Mytilus edulis [17, 49], Macoma balthica [56, 69], Mya arenaria [2, 12], etc.-is unlikely to have played a role in our study as there was no large temperature gradient across the study sites.
The growth rate of Mya arenaria is also known to be influenced by the population density $[7,48,59]$. We did not specially study this effect. However, at site 1 the numbers of clams in the middle intertidal zone were almost twice lower than in the low tidal zone throughout the observation period and yet no significant differences in the growth rates of clams from different tidal levels of site 1 were observed [37]. Therefore, as far as we can judge, population density was unlikely to play a role in determining the growth rates of clams in our study. 


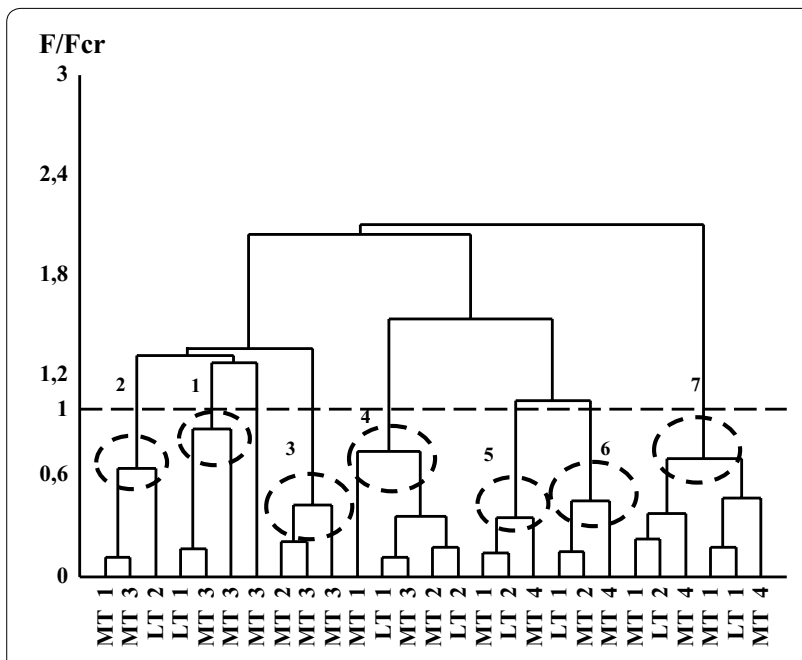

Fig. 7 Similarity dendrogram of group age rows, describing individual variability of the growth characteristics of 5-year-old molluscs in separate beds. Vertical axis is ratio $F / F_{c r}$; circles show clusters of age rows with no significant distinctions; $1-7$ cluster number

Food supply can have a great impact on the growth rate of bivalves. In case of filter feeders, indirect but reliable indicators of feeding conditions are hydrodynamic activity and, for intertidal species, duration of air exposure. To begin with the latter, the growth rate of Mya arenaria is known to be higher in low tidal and subtidal zones than in upper and middle tidal zones [52, 7, 46]. At the White Sea the average duration of air exposure in the middle tidal zone is about $12 \mathrm{~h}$, while at the low tidal zone, about $6 \mathrm{~h}$ [45]. However, we found no significant differences in the growth rate of clams in the low and the middle horizon of the same site.

Hydrodynamic activity, the second indirect indicator of feeding conditions, can, in turn, be inferred from sediment characteristics such as the size distribution of sediment particles. The slowest growth of soft-shell clams was observed at sites with the greatest content of fine particles (silt and clay) in the sediments. By the same token, the fastest growth was observed at site 4 where the proportion of silt and clay was the lowest. A negative correlation of Mya growth rate with the proportion of fine particles in sediments has been shown before [2]. So, we may be fairly sure that the differences in the growth rates of soft-shell clams revealed in our study were associated, at least, in part, with the differences in sediment characteristics across the sites.

This conclusion is also supported by a comparison of Mya growth rate that takes into account individual growth heterogeneity in different beds. All soft-shell clams at site 3 showed the slowest growth, while clams at

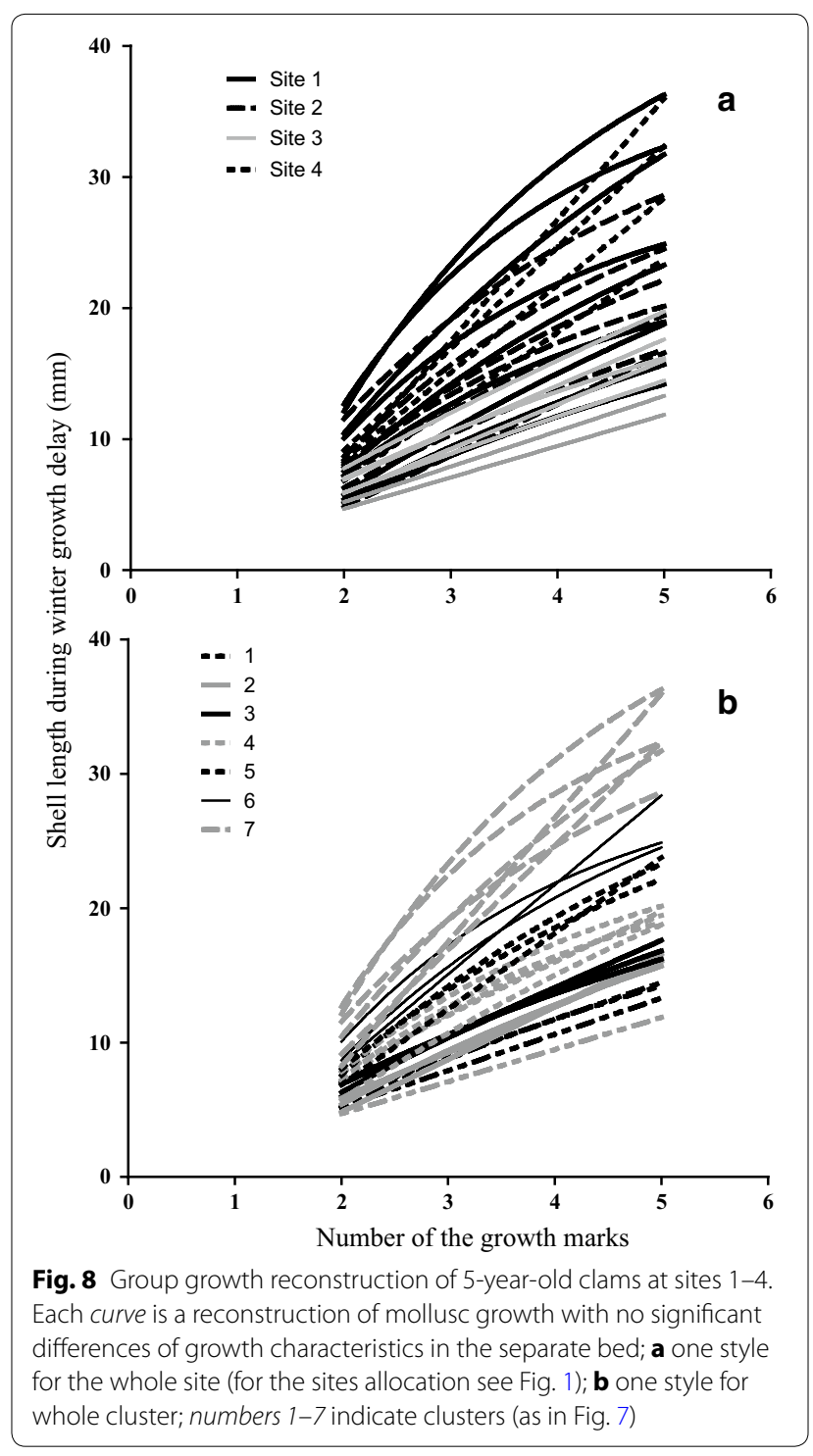

site 4 showed the fastest growth. No individuals at site 3 grew as fast as those at site 4 .

\section{Individual growth}

The variation of individual growth rate within the beds was similar to or exceeded that of group growth rate between the beds. The average size of 5-year-old clams in 1988 and 1999 generations varied from 18 to $36 \mathrm{~mm}$ between 6 studied beds, while the individual size varied from 11 to $43 \mathrm{~mm}$ in a single bed with the highest variation (location $\mathrm{MT}_{-} 1$ ).

As noted above, little is known about variation of $M y a$ arenaria growth rate within a bed. There are more data on other species, especially Mytilus edulis. Considerable variation in the shell length of the White Sea mussels 
Table 4 The average shell length $(L \pm \mathrm{SE}, \mathrm{mm})$ of Mya arenaria during 1-7 winter growth delays

\begin{tabular}{|c|c|c|c|c|c|c|}
\hline \multirow{3}{*}{$\begin{array}{l}\text { Number of } \\
\text { growth marks }\end{array}$} & \multicolumn{6}{|l|}{$L \pm S E$} \\
\hline & \multicolumn{6}{|l|}{ Location $^{a}$} \\
\hline & MT_1 & LT_1 & MT_2 & LT_2 & MT_3 & MT_4 \\
\hline 1 & $2.5 \pm 0.1$ & $2.6 \pm 0.01$ & $2.3 \pm 0.1$ & $2.3 \pm 0.1$ & $2.3 \pm 0.1$ & $2.2 \pm 0.1$ \\
\hline 2 & $9.0 \pm 0.2$ & $10.4 \pm 0.1$ & $8.5 \pm 0.1$ & $8.6 \pm 0.2$ & $5.7 \pm 0.1$ & $7.4 \pm 0.1$ \\
\hline 3 & $14.6 \pm 0.3$ & $16.6 \pm 0.2$ & $13.6 \pm 0.2$ & $13.0 \pm 0.2$ & $10.1 \pm 0.1$ & $14.1 \pm 0.2$ \\
\hline 4 & $19.4 \pm 0.5$ & $21.2 \pm 0.3$ & $17.1 \pm 0.3$ & $17.2 \pm 0.3$ & $13.3 \pm 0.2$ & $20.3 \pm 0.3$ \\
\hline 5 & $23.1 \pm 0.6$ & $23.9 \pm 0.4$ & $19.1 \pm 0.4$ & $19.8 \pm 0.4$ & $15.9 \pm 0.2$ & $28.3 \pm 0.5$ \\
\hline 6 & $28.7 \pm 1.9$ & $28.1 \pm 0.6$ & $20.5 \pm 0.4$ & $23.6 \pm 0.9$ & $21.5 \pm 0.6$ & $30.2 \pm 0.8$ \\
\hline 7 & $31.7 \pm 2.1$ & $30.5 \pm 1.1$ & $22.9 \pm 0.4$ & $26.7 \pm 0.8$ & $24.9 \pm 0.7$ & $33.8 \pm 0.9$ \\
\hline
\end{tabular}

SE standard error

a For location name see Table 2

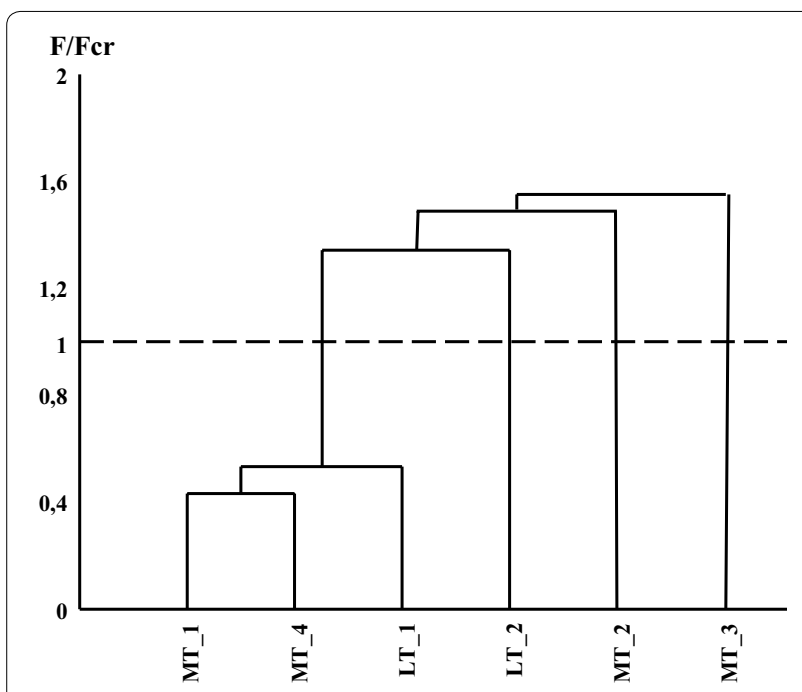

Fig. 9 Similarity dendrogram of group age rows (Table 4) 7-year-old clams at studied locations. Vertical axis is $F / F_{c r}$ ratio. Horizontal axis is location. For location names see Table 2

of the same age has often been noted [60, 63, 32]. The annual shell increment is shown to depend mostly on the shell size attained by the start of the growing season $[64,54,41,55,61]$. Moreover, the decisive influence of size by the start of the second growth season on later growth rate (during the entire life cycle) was shown for several bivalve species: Mytilus edulis [41], Mytilus trossulus [24], Macoma balthica [15], Macoma incongrua [38].

In the White Sea, this effect is partly due to the fact that the recruitment period is stretched over 2-3 months $[42,43,39]$. Differences in size by the start of the second growth season arise, to a large extent, from the difference in the time of juvenile settling. Clams that settled before

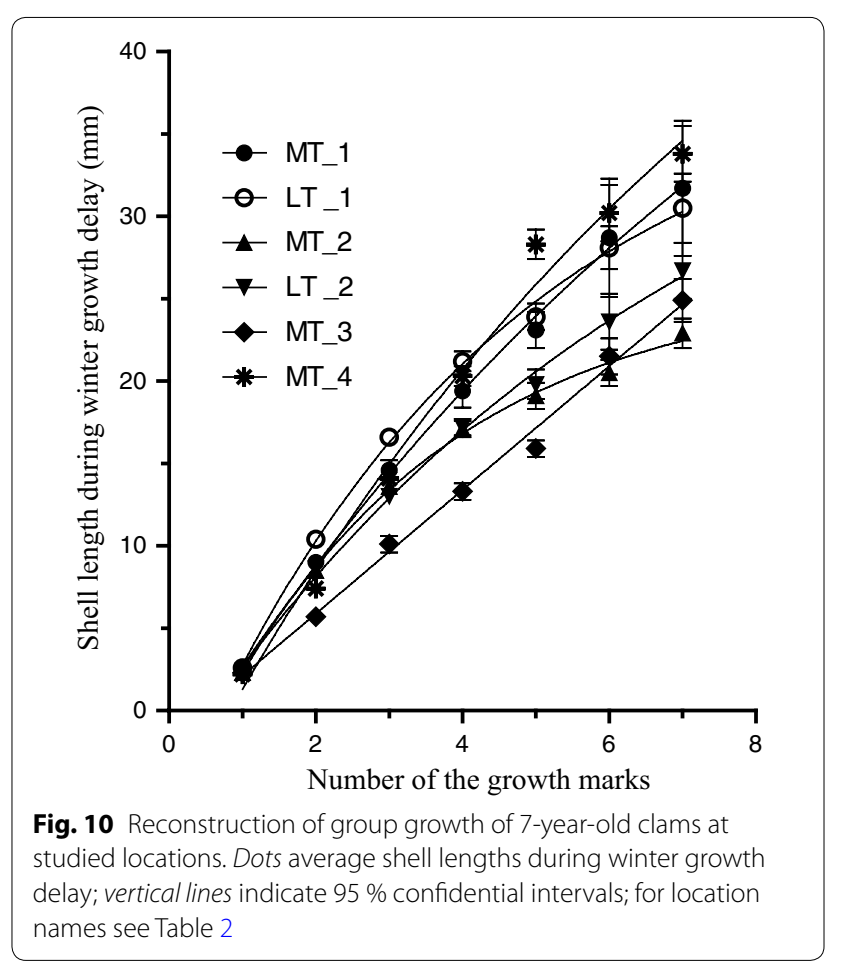

the others get larger by the first winter and probably grow faster for the rest of their lives. Because of a long recruitment period (2-3 months) of Mya arenaria beds, the size of clams during the first winter growth delay varied from 1.2 to $5.8 \mathrm{~mm}$ in location LT_1 (1988 generation) [40], i.e. the difference was almost five times.

Later on, the difference in the growth rate persisted. The dependence of the growth rate during the first year of life upon the size during first winter growth delay was almost linear (Spearman's rank correlation at different habitats 0.7-0.9). Seven-year-old clams of the 
1988 generation in LT_1 had a shell length of 21-49 mm (unpublished data). Compensatory growth was virtually observed in this case.

Genetic differences could also underlie the difference in the time of juvenile settling. Mytilus edulis from different cohorts, which settle at different times, are shown to differ genetically [29]. Unfortunately, there are no data on the genetic heterogeneity of Mya arenaria population in the White Sea.

Internal differentiation in $M y a$ beds in terms of growth rate may be accompanied by differentiation in respect of other properties, such as respiration rate and mortality. This kind of differentiation has been reported for mussels $[60,63]$. Apparently, individual growth characteristics can serve as an indicator of internal heterogeneity of bivalve beds. More detailed assessment of observed phenomenon requires additional data and may be the subject of further research.

\section{Conclusion}

Mya arenaria in the White Sea is characterized by slow growth and long lifespan. Its maximum size is $70-80 \mathrm{~mm}$, and longevity is at least 25 years. In addition, the heterogeneity in growth rate across the study sites was high. Statistically significant differences in growth rate were found both within beds and between beds situated quite close to each other.

The group growth curves obtained for local beds did not take into account internal the heterogeneity of the individual growth rate. However, the characteristics of group growth were seen as an integral assessment of environmental conditions at a particular site. No differences were found between different tidal horizons of the same site. The slowest growth of soft-shell clams was observed at sites with greatest content of fine particles (silt and clay) in sediments. The differences between the beds in respect of Mya group growth rate could reflect variability of feeding conditions, which were probably determined by some local features (e.g. hydrodynamic regime).

However, the variation of individual growth rate within beds was quite comparable with that of group growth rate between the study locations. To a great extent this variation of individual growth rate was, apparently, determined by the characteristics of the initial period of softshell clam growth.

It remains unclear whether the internal heterogeneity changes throughout the mollusc life cycle and whether it is accompanied by differentiation in other population characteristics, such as lifespan and mortality rate. It would be also interesting to estimate the proportion of groups significantly differing in the growth rate. All these aspects could be the subject of future research.

\section{Authors' contributions}

FMM participated in the sampling and sample processing (observations from 2001 to 2006). NAF participated in the sampling and sample processing (observations from 2008 to 2013), prepared illustrations for the article. NVM participated in the sampling and sample processing (observations from 1980 to 2013), participated in the preparation of the manuscript. AVG participated in the sampling and sample processing (observations from 1989 to 2013), drafted the manuscript. All authors read and approved the final manuscript.

\section{Acknowledgements}

We are grateful to the staff and the students of the Department of Ichthyology and Hydrobiology, St Petersburg State University, for their help in the sampling of clams and the analysis of the data. This work was supported by the St Petersburg State University, Grant No. 1.38.253.2014.

\section{Competing interests}

The authors declare that they have no competing interests.

Received: 3 August 2015 Accepted: 4 January 2016

Published online: 20 April 2016

\section{References}

1. Abraham BJ, Dillon PL. Species profiles: life histories and environmental requirements of coastal fishes and invertebrates (Mid-Atlantic): softshell clam. Biological report. Washington, DC, vol 82(11.68). 1986.

2. Appeldoorn RS. Variation in the growth rate of Mya arenaria and its relationship to the environment as analyzed through principal component analysis and the w parameter of von Bertalanffy equation. Fish Bull. 1983;81(1):75-85.

3. Appeldoorn RS. Covariation in life history parameters of soft-shell clams, Mya arenaria along a latitudinal gradient. In: ICES marine science symposium. 1995. p. 19-25.

4. Azouzi $L$, Bourget E, Borcard D. Spatial variation in the intertidal bivalve Macoma balthica: biotic variables in relation to density and abiotic factors. Mar Ecol Prog Ser. 2002;234:159-70.

5. Babkov Al, Golikov AN. Hydrobiocomplexes of the White Sea. Leningrad: Publishing House of Zoological Institute; 1984 (in Russian).

6. Beal BF. Relative importance of predation and intraspecific competition in regulating growth and survival of juveniles of the soft-shell clam, Mya arenaria L., at several spatial scales. J Exp Mar Biol Ecol. 2006;336(1):1-17.

7. Beal BF, Parker MR, Vencile KW. Seasonal effects of intraspecific density and predator exclusion along a shore-level gradient on survival and growth of juveniles of the soft-shell clam, Mya arenaria L., in Maine, USA. J Exp Mar Biol Ecol. 2001;264(2):133-69.

8. Belding DL. The soft-shelled clam fishery of Massachusetts: including the natural history of the soft-shelled clam and a discussion of sewage pollution and shellfish. Marine fisheries series, vol 1. Commonwealth of Massachusetts, Dept. of Conservation, Division of Fisheries and Game, Marine Fisheries Section, Boston; 1930.

9. Berger V, Dahle S, Galaktionov K, Kosobokova X, Naumov A, Rat'kova T, et al. White Sea. Ecology and environment. St Petersburg: Zoological Institute Russian Academy of Sciences; 2001.

10. Berger VJ. Production potential of the White Sea. Exploration of fauna of the seas, vol 60 (68). Zoological Institute of Russian Academy of Sciences, St. Petersburg. 2007 (in Russian).

11. Beukema JJ, Cadee GC, Jansen JJ. Variability of growth rate of Macoma balthica (L.) in the Wadden Sea in relation availability of food. In: Biology of benthic organisms. 11th European symposium marine biology, 1977. Oxford: Pergamon Press; 1977. p. 69-77.

12. Brousseau DJ. Analysis of growth rate in Mya arenaria using the Von Bertalanffy equation. Mar Biol. 1979;51(3):221-7.

13. Cardoso JFMF. Growth and reproduction in Bivalves. An energy budget approach. Groningen: University of Groningen; 2007.

14. Carmichael RH, Shriver AC, Valiela I. Changes in shell and soft tissue growth, tissue composition, and survival of quahogs, Mercenaria mercenaria, and softshell clams, Mya arenaria, in response to eutrophicdriven changes in food supply and habitat. J Exp Mar Biol Ecol. 2004;313(1):75-104. 
15. Cloern JE, Nichols FH. A von Bertalanffy growth model with a seasonally varying coefficient. J Fish Res Board Can. 1978;35(11):1479-82.

16. Commito JA. Effects of Lunatia heros predation on the population dynamics of Mya arenaria and Macoma balthica in Maine, USA. Mar Biol. 1982;69(2):187-93.

17. Dare PJ. Settlement, growth and production of the mussel, Mytilus edulis L., in Morecambe Bay, England. Fishery investigations. Ser. II, vol 28(1). London: Her Majesty's Stationery Office; 1976.

18. Dekker R, Beukema JJ. Long-term and large-scale variability in productivity of the tellinid bivalve Macoma balthica on Wadden Sea tidal flats. Mar Ecol Prog Ser. 2007;337:117-34.

19. Emerson CW, Minchinton TE, Grant J. Population structure, biomass, and respiration of Mya arenaria L. on temperate sandflat. J Exp Mar Biol Ecol. 1988;115(2):99-111.

20. Evans S, Tallmark B. Growth and biomass of bivalve molluscs on a shallow, sandy bottom in Gullmar Fjord (Sweden). Zoon. 1977;5(1):33-8.

21. Feder HM, Paul AJ. Age, growth and sizeweight relationships of the soft-shelled clam Mya arenaria in Prince William Sound, Alaska. Proc Natl Shellfish Assoc. 1974;64:45-52

22. Filippenko D. Filtration activity of mollusks Mya arenaria L. (Bivalvia) in estuaries of the southern Baltic Sea. Vestnik the Baltic Federal University. 2013;7:51-5 (in Russian)

23. Filippenko D, Naumenko E. Patterns of the growth of soft-shell clam Mya arenaria L. (Bivalvia) in shallow water estuaries of the southern Baltic Sea. Ecohydrol Hydrobiol. 2014;14(2):157-65.

24. Gagaev SY, Golikov AN, Sirenko BI, Maximovich NV. Ecology and distribution of the mussel Mytilus trossulus septentrionalis Clessin, 1889 in the Chaun inlet of the East Siberian Sea. In: Ecosystems, flora and fauna of Chaun inlet of the East Siberian Sea. Part I. Exploration of fauna of the seas, vol 44 (55). 1994. p. 254-258 (in Russian)

25. Gerasimova AV, Ivonina NY, Maximovich NV. The length growth rate variability of Mytilus edulis I. (Mollusca, Bivalvia) in the waters of the Keret Archipelago (Kandalaksha Bay, the White Sea). Vestnik St Petersburg Univ Ser 3 Biol. 2014:4:22-38 (in Russian)

26. Gerasimova A, Maximovich N. Age-size structure of common bivalve mollusc populations in the White Sea: the causes of instability. Hydrobiologia. 2013;706(1):119-37.

27. Gerasimova A, Maximovich N, Filippova N. Cohort life tables for a population of the soft-shell clam, Mya arenaria L., in the White Sea. Helgol Mar Res. 2015;69(2):141-58.

28. Golikov AN, Maximovich NV, Sirenko BI. Features of distribution, growth and production of Mytilus edulis L. in different habitats on the example of beds near Sonostrova. In: Hydrobiological features of the southeastern part of the Kandalaksha Bay in connection with mussel mariculture in the White Sea. Explor Fauna Seas. 1988; 39(47):97-108 (in Russian).

29. Gosling EM, Wilkins NP. Genetics of settling cohorts of Mytilus edulis (L.): preliminary observations. Aquaculture. 1985;44(2):115-23.

30. Ivanov Al. Introduction of fishing clam Mya arenaria L. in the Black Sea: extension of the area, population dynamics and some features of its biology in new conditions. In: Proceedings of all-union symposium on the study of the Black and Mediterranean seas, exploitation and protection of resources. 1973. p. 58-60 (in Russian).

31. Jorgensen CB. Bivalve filter feeding: hydrodynamics, bioenergetics, physiology and ecology. Fredensborg: Olsen and Olsen; 1990.

32. Kulakovskii EE, Kunin BL. Preliminary results for growing mussels on artificial substrates in the White Sea. In: Ecological studies of mariculture perspective objects in the fauna of the White Sea. Exploration of fauna of the seas, vol 27(35). Leningrad: Zoological Institute of Russian Academy of Sciences; 1982. p. 17-24 (in Russian).

33. MacDonald BA, Thomas MLH. Age determination of the soft-shell clam Mya arenaria using shell internal growth lines. Mar Biol. 1980;58(2):105-9.

34. Maximovich NV. Peculiarities of ecology and bioenergetic traits of population of Mya arenaria L. (Bivalvia) in the Chupa Inlet. Vestnik Leningrad Univ Ser 3 Biol. 1978;3(21):28-36 (in Russian).

35. Maximovich NV. Statistical comparison of growth curves. Vestnik Leningrad Univ Ser 3 Biol. 1989;4(24):18-25 (in Russian)

36. Maximovich NV. Dynamics of production traits in littoral bed of Mya arenaria L. (The Chupa Inlet, The White Sea). Vestnik Leningrad Univ Ser 3 Biol. 1989;1:19-24 (in Russian)

37. Maximovich NV, Guerassimova AV. Life history characteristics of the clam Mya arenaria in the White Sea. Helgol Mar Res. 2003;57:91-9.
38. Maximovich NV, Lysenko VI. Growth and production of the bivalve Macoma incongrua in Zostera beds in the Knight Bay, Sea of Japan. Biol Morya. 1986;1:25-30 (in Russian)

39. Maximovich NV, Shilin MB. Spatial-temporal distribution of Bivalve planktonic larvae in the semi-isolated waters (for example, Chupa Inlet of the White Sea). Biosphera. 2012;4(3):293-306 (in Russian).

40. Maximovich NV, Gerasimova AV. Age determination of the White Sea bivalves by the shell morphology. In: Proceedings of the $V$ Scientific Session of the Marine Biological Station of St. Petersburg State University, St. Petersburg, Russia, February 6 2004. St. Petersburg;2004. pp. 29-30 (in Russian).

41. Maximovich NV, Minichev YS, Kulakovskii EE, Sukhotin AA, Chemodanov AV. Dynamics of structural and functional characteristics of the White Sea mussel beds in the suspended aquaculture. In: Research mariculture White Sea mussels. Proceedings of Zoological Institute of Russian Academy of Sciences, vol 253. St. Petersburg; 1993. p. 61-82 (in Russian).

42. Maximovich NV. Peculiarities of ecology and reproductive cycle of Macoma balthica L. in the Chupa Inlet. In: Skarlato OA, editors. Biocenoses of the White Sea Chupa Inlet and their seasonal dynamics. Explor Fauna Seas. 1985; 31(39):230-243 (in Russian)

43. Maximovich NV. The reproductive cycle of Mytilus edulis L. in the Chupa Inlet. In: Investigation of White Sea mussels. Leningrad. 1985. p. 22-35 (in Russian).

44. Munch-Petersen S. An investigation of a population of the soft clam Mya arenaria $L$ in a Danish estuary. Medd Dan Fisk Havunders NY Ser. 1973;7(1-3):47-73.

45. Naumov AD, Fedyakov W. Ever-living the White Sea. St. Petersburg. 1993 (in Russian)

46. Newcombe CL. Growth of Mya arenaria L. in the bay of Fundy Region. Can J Res. 1935;13(6):97-137.

47. Newell CR, Hidu $\mathrm{H}$. The effects of sediment type on growth rate and shell allometry in the soft shelled clam Mya arenaria L. J Exp Mar Biol Ecol. 1982;65(3):285-95.

48. Newell CR, Hidu H. Species profiles: life histories and environmental requirements of coastal fishes and invertebrates (North Atlantic): softshell clam. Biological report (Washington, DC), vol 82(11.53). 1986.

49. Ozernyuk ND, Zotin AA. Comparative analysis of growth of edible mussel Mytilus edulis from different White Sea regions. Biol Bull. 2006:33(2):149-52.

50. Petelin VP. Analysis of particle size distribution of marine sediments. Moscow (in Russian): Nauka; 1967.

51. Petersen GH. Life cycles and population dynamics of marine benthic bivalves from the Disko Bugt area of West Greenland. Ophelia. 1978;17(1):95-120.

52. Roseberry L, Vincent B, Lemaire C. Croissance et reproduction de Mya arenaria dans la zone intertidale de l'estuaire du Saint-Laurent. Can J Zool. 1991;69(3):724-32.

53. Sadykhova IA. Biological features of Mya arenaria (Mollusca, Lamellibranchia) in the White Sea. Zool J. 1979;58(6):804-9 (in Russian).

54. Savilov Al. Growth and its variability in the White Sea invertebrates Mytilus edulis, Mya arenaria and Balanus balanoides. Part I. Mytilus edulis in the White Sea. Proc Inst Oceanol USSR Acad Sci. 1953;7:198-258 (in Russian).

55. Seed R. The ecology of Mytilus edulis L. (Lamellibranchiata) on exposed rocky shores. II. Growth and mortality. Oecologia. 1969;3(3-4):317-50.

56. Segerstrale SG. Investigation on baltic populations of the bivalve Macoma balthica (L.). Part. 1. Introduction. Studies on recruitment and its relation to depth in Finnish coastal waters during the period 1922-1959. Age and Growth. Societas Scientiarum Fennicae Commentationes Biologicae, vol 23(2), Helsingfors. 1960.

57. Shklyarevich GA, Shcherbakova IB. Long-term changes of Mya arenaria beds in the intertidal zone of Kandalaksha Bay (White Sea). In: Proceedings of the IXth international conference "The study, sustainable use and conservation of natural resources of the White Sea", Petrozavodsk, Karelia, 11-14 October 2004. Petrozavodsk; 2005. p. 327-332 (in Russian).

58. Spear HS, Glude JB. Effects of environment and heredity on growth of the soft clam (Mya arenaria). Fish Bull. 1957:57(114):279-92.

59. Strasser M, Walensky M, Reise K. Juvenile-adult distribution of the bivalve Mya arenaria on intertidal flats in the Wadden Sea: why are there so few year classes? Helgol Mar Res. 1999;53(1):45-55 
60. Sukhotin AA. Respiration and energetics in mussels (Mytilus edulis L.) cultured in the White Sea. Aquaculture. 1992;101(1-2):41-57.

61. Sukhotin AA, Abele D, Portner H-O. Growth, metabolism and lipid peroxidation in Mytilus edulis: age and size effects. Mar Ecol Prog Ser 2002;226:223-34.

62. Sukhotin AA, Kulakovskii EE, Maximovich NV. Length growth of the White Sea mussel in habitat condition changes. Ekologiya. 1992;5:71-2 (in Russian).

63. Sukhotin AA, Kulakowski EE. Growth and population dynamics in mussels (Mytilus edulis L.) cultured in the White Sea. Aquaculture. 1992;101(1-2):59-73.

64. Sukhotin AA, Maximovich NV. Variability of growth rate in Mytilus edulis L. from the Chupa Inlet (the White Sea). J Exp Mar Biol Ecol. 1994;176(1):15-26.
65. Sukhotin AA, Strelkov PP, Maximovich NV, Hummel H. Growth and longevity of Mytilus edulis (L.) from northeast Europe. Mar Biol Res. 2007;3(3):155-67.

66. Sveshnikov VA. Biocenotic relations and environmental conditions of some food invertebrates of intertidal infauna in the Kandalaksha Bay of the White Sea. Proc Kandalaksha Reserve. 1963;4:114-34 (in Russian).

67. Swan EF. Growth indices of the clam Mya arenaria. Ecology. 1952;33(3):365-74.

68. Warwick RM, Price R. Macrofauna production in an estuarine mud-flat. J Mar Biol Assoc UK. 1975;55(1):1-18.

69. Wenne R, Klusek Z. Longevity, growth and parasites of Macoma balthica (L.) in the Gdansk Bay (South Baltic). Pol Arch Hydrobiol. 1985;32(1):31-45.

70. Zolotarev VN. Long-term rhythms of Crenomytilus grayanus growth shell. Ekologiya. 1974;3:76-80 (in Russian).
Submit your next manuscript to BioMed Central and we will help you at every step:

- We accept pre-submission inquiries

- Our selector tool helps you to find the most relevant journal

- We provide round the clock customer support

- Convenient online submission

- Thorough peer review

- Inclusion in PubMed and all major indexing services

- Maximum visibility for your research

Submit your manuscript at www.biomedcentral.com/submit
(OioMed Central 